\title{
POSTPARTUM DEPRESSION and ANXIETY: CAN THEY BE THE CAUSE OF NEONATAL HYPERNATREMIA?
}

\section{Kiymet Celik ${ }^{1}$, Ozgur Olukman ${ }^{1}$, Figen Isleten ${ }^{2}$, Aylin Ozbek ${ }^{3}$, Sebnem Calkavur ${ }^{1}$}

1 Dr. Behcet Uz Children Hospital, Departments of Neonatology

2 Dr. Behcet Uz Children Hospital, Departments of Biochemistry

${ }^{3}$ Dokuz Eylul University Medical Faculty Departments of Child Psychiatry

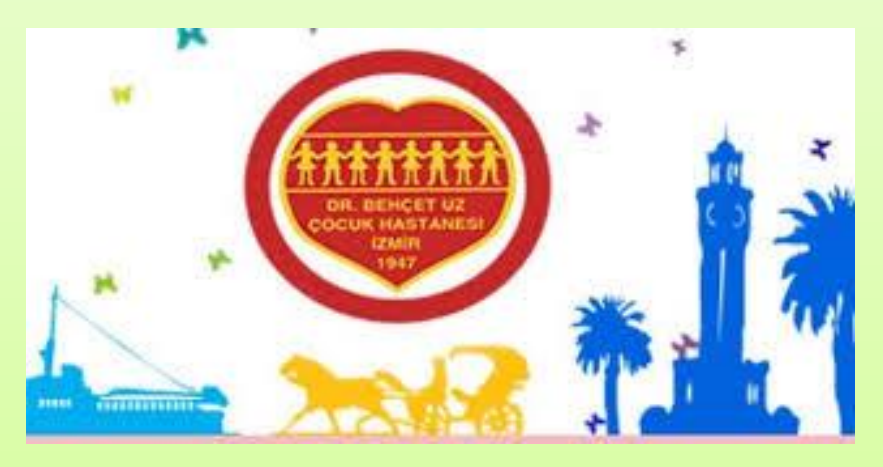

INTRODUCTION: Due to its nutritional, as well as nonnutritional benefits both for the mother and her infant, breastfeeding is the optimal type of infant feeding. Many factors such as cultural models, anxiety, psychosocial and emotional stress of the mother can influence initiating and maintaining lactation. It's well known that postpartum depression and anxiety (PPDA) have an effect upon the frequency of lactation and the content of breastmilk. In this prospective-case controlled study, we investigated the possible effects of PPDA on breastmilk sodium levels and neonatal hypernatremia.

MATERIALS-METHODS: The study group consisted of 47 exclusively breastfed, term neonates with hypernatremic dehydration and the control group consisted of 96 jaundiced, term neonates without dehydration. While recording patients' demographical features, mothers were asked to fill out sociodemographical/psychosocial data form, Edinburgh Postnatal Depression Scale (EPDS) and State-Trait Anxiety Inventory (STAI) I/II. Breastmilk sodium levels were measured from all mothers. Breast milk sodium levels, Koo and Gupta in the study of breast milk reference sodium level; evaluated as high or low / normal. Factors affecting breastmilk sodium levels, relationship between hypernatremic dehydration and PPDA and the factors affecting this possible relationship were compared between the groups.

RESULTS: The mean sodium level of the patients with hypernatremic dehydration was $155 \pm 3.5 \mathrm{mEq} / \mathrm{L}$ and the mean dehydration percentage was $11.9 \%( \pm 3.2)$. The median admission time was $3(2-26)$ in the study group and 5 (1-21) days in the control group, no significant difference was found between the groups. Mean breastmilk sodium level in the study group was 25.8 (7.9) $\mathrm{mmol} / \mathrm{L}$ and was significantly higher than the control group $(p=0.008)$. Among all risk factors, "being the first child" was the only significant risk factor for hypernatremic dehydration $(p=0.003)$. Comparison of EPDS between the groups didn't reveal any significant difference (median score of the study group: 6 (0-20), median score of the control group: 6 (0-23)). Comparison of STAI-I and STAI-II scales between the groups showed that while state and trait anxiety was higher in the control group $(p=0.001)$, anxiety score was higher in the study group $(p=0.001)$.
Table 1: Comparison of groups on maternal psychosocial characteristics

\begin{tabular}{|c|c|c|c|}
\hline & Cases with HND & Control & $\mathbf{p}$ \\
\hline Mother age * & $27.1(5)$ & $28.7(5.8)$ & 0.106 \\
\hline $\begin{array}{l}\text { Maternal educational level } n(\%) \\
\text { Elementary education } \\
\text { High school } \\
\text { University }\end{array}$ & $\begin{array}{l}13(27) \\
18(38) \\
16(34)\end{array}$ & $\begin{array}{l}34(35) \\
35(36.5) \\
27(28)\end{array}$ & 0.334 \\
\hline $\begin{array}{l}\text { Maternal occupational status n(\%) } \\
\text { Employed } \\
\text { Unemployed }\end{array}$ & $\begin{array}{l}17(36.2) \\
30(63.8)\end{array}$ & $\begin{array}{l}25(26) \\
71(74)\end{array}$ & 0.212 \\
\hline $\begin{array}{l}\text { Number of mother pregnancy } n(\%) \\
\text { Primipar } \\
\text { Multipar }\end{array}$ & $\begin{array}{l}34(72.3) \\
13(27.7)\end{array}$ & $\begin{array}{l}44(46.3) \\
52(53.7)\end{array}$ & 0.003 \\
\hline $\begin{array}{l}\text { Abortion } n(\%) \\
\text { Yes } \\
\text { No }\end{array}$ & $\begin{array}{l}8(17) \\
39(83)\end{array}$ & $\begin{array}{l}24(25) \\
72(75)\end{array}$ & 0.282 \\
\hline $\begin{array}{l}\text { Competence in baby care } n(\%) \\
\text { Feels enough } \\
\text { Feeling inadequate }\end{array}$ & $\begin{array}{l}38(80.9) \\
9(19.1)\end{array}$ & $\begin{array}{l}81(85.3) \\
14(14.7)\end{array}$ & 0.502 \\
\hline $\begin{array}{l}\text { Complain about the baby? n(\%) } \\
\text { Yes } \\
\text { No }\end{array}$ & $\begin{array}{l}12(25.5) \\
35(74.5)\end{array}$ & $\begin{array}{l}22(22.9) \\
74(77.1)\end{array}$ & 0.849 \\
\hline $\begin{array}{l}\text { Residents of the house } n(\%) \\
\text { Nuclear family } \\
\text { Extended family }\end{array}$ & $\begin{array}{l}40(85.1) \\
7(14.9)\end{array}$ & $\begin{array}{l}89(93.7) \\
6(6.3)\end{array}$ & 0.097 \\
\hline $\begin{array}{l}\text { Pregnancy planning } n(\%) \\
\text { Planned } \\
\text { Unplanned }\end{array}$ & $\begin{array}{l}37(78.7) \\
10(21.3)\end{array}$ & $\begin{array}{l}73(76.8) \\
22(23.2)\end{array}$ & 0.801 \\
\hline
\end{tabular}

Table 2: Comparison of mothers' scores on State and Trait Anxiety Inventory (STAI-I and II) and Edinburgh Postpartum Depression Inventory (PDI

\begin{tabular}{|l|l|l|l|} 
& Cases with HND & Control & P \\
\hline STAI-I (mean) & $33.9(9.6)$ & $39.8(9.7)$ & 0.001 \\
\hline STAI-II (mean) & $35.8(8.3)$ & $40.9(7.7)$ & 0.001 \\
\hline $\begin{array}{l}\text { Edinburgh PDI } \\
\text { (median) }\end{array}$ & $6(0-20)$ & $6(0-23)$ & 0.169 \\
\hline
\end{tabular}

CONCLUSiON: During nursing period, mothers should psychosocially be encouraged. It should be kept in mind that especially undereducation about lactation and being primigravid, can result in high breastmilk sodium levels and neonatal hypernatremia. 